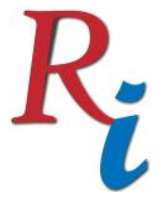

Asia Proceedings of Social Sciences

(APSS)

www.readersinsight.net/APSS

\title{
EXPLORATION OF HISTORICAL LEARNING STRATEGIES AT SMAN 37 JAKARTA
}

\section{Nur'aeni Marta*}

Departement of Educational history

Universitas Negeri Jakarta

Indonesian

\section{Robinson Situmorang}

Departement of Educational Technology

Universitas Negeri Jakarta

Indonesia

*Corrosponding author's Email: nuraeni@unj.ac.id

Peer-review under responsibility of 5 th $^{d}$ Asia International Conference 2019 Scientific Committee

http://connectingasia.org/scientific-committee/

(C) 2019 Published by Readers Insight Publisher, lat 306 Savoy Residencia, Block 3 F11/1,44000 Islamabad. Pakistan,

editor@ readersinsight.net

This is an open access article under the CC BY-NC-ND license (http://creativecommons.org/licenses/by-nc-nd/4.0/). 


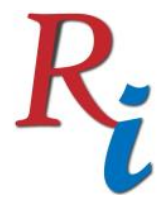

Asia Proceedings of Social Sciences

(APSS)

www.readersinsight.net/APSS

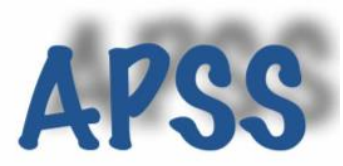

\section{A b s tract}

This study aims to figure out the history teacher creativity in developing in history instruction variations in class. The subject matter of history has distinction characteristic with other subject, because history concern with the past. The historical characteristic became challenges for the history teacher to create variation in instructional, in order to make instructional activity more pleasure. This study using the qualitative method. The Material for this study acquiring from the key informan and core informan based on purposive sampling. The Curiculum of 2013 highlights that in the history instructional activity, the teacher has not only learn about the rememberes facts but also meaning behind it. The teacher has to develop a kind of creativity in instructional variation to stimulate the student eager in learning. The study shows that the SMAN 37 Jakarta history teacher ability in instructional activity resulting some creation in class management by activity involving student in history learning in class. The teacher creativity still limited in make condusive circumstance in learning by using variative methods. Meanwhile, there still rare effort in creation of developing of learning material. The teacher creativity still limeted in the problem of knowledge transfering.

\section{Research High I ight s}

History teacher is the implementer of the national education curriculum in the field. His role as an educator, teachers must be able to convey subject matter clearly and interestingly, so that students understand and are enthusiastic about following the learning process. A teacher does not merely convey what is written in a textbook, but the teacher must be able to communicate the material / teaching material well, so that the material being taught is meaningful and useful for students. (Husbands et al., 2003) As educators, teachers must be able to have creativity in developing variations of teaching, so that learning activities in history are not monotonous

Keyword: Exploration, Historical, Learning Strategies 


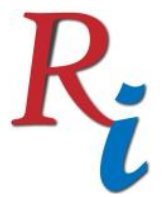

Asia Proceedings of Social Sciences

(APSS)

www.readersinsight.net/APSS

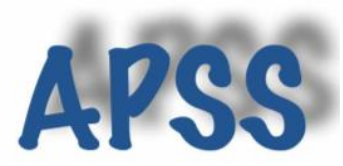

\section{Research Objectives}

The purpose of this research is to find the history teacher's creativity in developing variations of learning in the classroom. Image boring history learning is a challenge for history teachers to have the creativity to develop innovation so that the learning model of history is varied and not monotonous. The history teacher is required not only to convey what is written in the textbook, but the significance of the meaningfulness of the events learned for students' real lives (Klein, 2005). Therefore, learning activities in history need variations that are tailored to the needs and conditions of students in the class. Learning variations include the use of various methods, teaching styles, the use of teaching material resources. Monotonous learning history will lead to boredom, which impacts students becoming passive, less participating in learning activities. This is where the importance of the history teacher's role is to have creativity to develop variations of learning so that history learning runs effectively and fun (Boadu, 2015).

\section{Methodology}

The research method was qualitative with a case study approach at SMAN 37 Jakarta. Data collection using purposive sampling method. Data collection techniques by interviewing key and key informants, observation, observation and documentation. Data analysis techniques using triangulation. Key informants are the school principal and curriculum representatives. While the core informants are subject teachers and students

\section{Results}

The results showed that effective and enjoyable teaching history was not easy. Historical studies are past events and have occurred that cannot be repeated. To be able to demonstrate the importance of learning history, teachers need to create varied learning models. The lack of creativity of history teachers in developing variations of learning is due to the low competence and creativity of teachers. The creative teacher will be able to utilize various kinds of learning resources that are around him, and be able to develop a variety of learning methods. From the results of the study found some of the creativity of history teachers at SMAN 37 Jakarta in developing variations of learning in the form of games methods. Some 


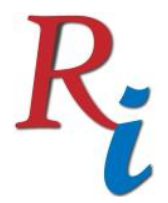

\section{Asia Proceedings of Social Sciences}

(APSS)

www.readersinsight.net/APSS

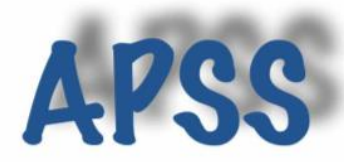

of the game methods used to overcome student boredom are flag games, chess games, games without tick boom. These learning variations are used to solve the problem of historical learning activities, namely the low participation of students in historical learning activities. There are two things that need to be considered by teachers in developing variations of learning methods, namely classroom conditions / student needs, and the characteristics of subject matter.

\section{Findings}

Although the creativity of the history teacher at SMAN 37 Jakarta is more aimed at making it easier for students to remember historical facts, it can effectively involve students to actively participate in learning activities. At SMAN 37 since 2013, the curriculum has been implemented in 2013, but in practice it does not follow the procedures as stipulated in Permendikbud number 69 of 2013 concerning the basic framework and curriculum structure of Senior High Schools / Madrasyah Aliyah. The process of history learning activities still emphasizes the results, ie students can answer or work on exam questions and get grades above the minimum competency criteria. Thus learning history emphasizes more on cognitive abilities, while the 2013 curriculum explicitly aims at achieving cognitive, affective and skill competencies.

\section{Acknowledgement}

The teacher's creativity in developing variations of learning is proven to have an effect on increasing student interest in learning. Teacher creativity is very dependent on the competence of the teacher concerned. Characteristics of special history subjects should be taught by professional history teachers, those who have historical and pedagogical scientific abilities. Professional teachers will be able to develop creativity to be able to create effective and fun learning.

\section{References}

Boadu, G. (2015). Effective Teaching in History: The Perspectives of History StudentTeachers. International Journal of Humanities and Social Sciences. 


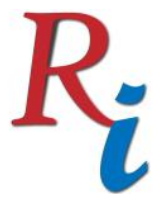

\section{Asia Proceedings of Social Sciences}

(APSS)

www.readersinsight.net/APSS

Klein, S. R. E. (2005). Understanding history teaching. Teaching and Teacher Education. https://doi.org/10.1016/j.tate.2005.03.009

Author's Biography

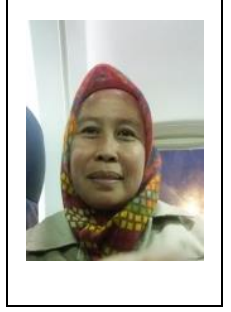

Nur'aeni Marta Born in Cirebon, September 22, 1971, started education in elementary school and graduated in 1985, Junior High School in 1988, and graduated from high school in 1991. Continuing her Bachelor's Education and graduating as a Bachelor of History in 1997 , then followed the master's program in the History study program and graduated in 2008. in 2014 continued the Doctoral program in the Education Technology study program at Universitas Negeri Jakarta. Currently a career as a lecturer at the Faculty of Social Sciences Historical Education study program at Universitas Negeri Jakarta. 